\title{
Pengaruh Frekuensi Pemberian Pakan dan Awal Pemberian Pakan terhadap Performa Ayam Buras Super
}

\author{
Effect of Feeding Frequency and Initial Feeding Time on Crossbred Native Chicken \\ Performance
}

\author{
E. Rahmawati, E. Suprijatna dan D. Sunarti \\ Faculty of Animal Husbandry and Agriculture \\ University of Diponegoro, Semarang, 50275 \\ email:evy.rahmawati1994@gmail.com
}

\begin{abstract}
This study was aimed to determine the effect of interaction between feeding frequency with initial feeding time on crossbred native chicken performance. This research was used 252 one day old unsex crossbred native chickens with the average weight of $37,88 \pm 1,89 \mathrm{~g}$ (CV: 5,02\%). The diet used was commercial feed. The experimental design was Split Plot Design with three levels of feeding frequency as main plot (F1: once feeding frequency, F2: twice feeding frequency, F3: thrice feeding frequency) and three levels of initial feeding time as sub plot (A1: initial feeding time at 04:00, A2: initial feeding time at 06:00, A3: initial feeding time at 08:00) in four replications which made 36 experimental units, each unit was consisted of seven chickens. Data was analyzed using analysis of variance and $\mathrm{F}$ test at 5\% level. The result showed that the interaction between feeding frequency with initial feeding time was not significantly different $(\mathrm{P}>0,05)$, as well as each treatment did not significantly effect $(\mathrm{P}>0,05)$ on crossbred native chicken performance, but from the view of economic value based on sales and feed cost, F3A1 (thrice feeding frequency with initial feeding time at 04:00) was the best combination treatment giving the highest Income Over Feed Cost.
\end{abstract}

Key words : crossbred native chicken, feeding, feeding, frequency, initial time, performance

\begin{abstract}
ABSTRAK
Penelitian ini bertujuan untuk mengetahui pengaruh interaksi frekuensi pemberian pakan dengan awal pemberian pakan terhadap performa ayam buras super. Materi yang digunakan adalah 252 ekor anak ayam buras super unsex umur 1 hari dengan rata-rata bobot badan awal 37,88 $\pm 1,89 \mathrm{~g}(\mathrm{CV}=5,02 \%)$. Pakan yang digunakan adalah pakan komersial. Rancangan percobaan yang digunakan adalah Split Plot Design dengan main plot yaitu 3 taraf frekuensi pemberian pakan $(\mathrm{F} 1=$ frekuensi pemberian pakan 1 kali, $\mathrm{F} 2=$ frekuensi pemberian pakan 2 kali, F3 = frekuensi pemberian pakan 3 kali) dan sub plot yaitu 3 taraf awal pemberian pakan $(\mathrm{A} 1=$ awal pemberian pakan pukul 04:00 WIB, A2 = awal pemberian pakan pukul 06:00 WIB, A3 = awal pemberian pakan pukul 08:00 WIB) dalam 4 ulangan sehingga terdapat 36 unit percobaan, tiap unit percobaan terdiri dari 7 ekor ayam. Data yang diperoleh dianalisis menggunakan analisis ragam dan uji $\mathrm{F}$ pada taraf 5\%. Hasil penelitian menunjukkan bahwa pengaruh interaksi antara frekuensi pemberian pakan dengan awal pemberian pakan tidak nyata $(p>0,05)$, demikin pula masing-masing perlakuan tidak menimbulkan pengaruh yang nyata $(p>0,05)$ terhadap performa ayam buras super, tetapi jika dilihat dari keuntungan ekonomis berdasarkan selisih antara total penjualan dan biaya pakan, kombinasi perlakuan F3A1 (frekuensi pemberian pakan 3 kali dengan awal pemberian pakan pukul 04:00 WIB) menunjukkan hasil terbaik.
\end{abstract}

Kata kunci : ayam buras super, performa, pemberian pakan, frekuensi, awal

\section{PENDAHULUAN}

Dewasa ini permintaan konsumen terhadap daging ayam lokal semakin meningkat, namun kemampuan produksi ayam lokal yang lambat mengakibatkan terjadi kekosongan pasokan. Maka dilakukan upaya untuk memperbaiki kualitas ayam lokal dengan perbaikan mutu genetis melalui persilangan antara ayam lokal dengan ayam ras yang disebut ayam buras super. Ayam buras super mampu mencapai bobot $0,85 \mathrm{~kg}$ dalam 
waktu 2 bulan pemeliharaan dibandingkan dengan ayam kampung yang hanya mencapai bobot $0,50 \mathrm{~kg}$ (Muryanto et al., 2009). Selain perbaikan mutu genetis, ditunjang perbaikan manajemen khusunya untuk mengatasi masalah pemberian pakan dengan memperhatikan faktor lingkungan. Hal itu dilatarbelakangi oleh lingkungan tropis di Indonesia yang lembab dan panas dengan temperatur berfluktuasi sehingga menentukan perilaku makan ayam. Indonesia sebagai negara yang terletak di daerah ekuator, memiliki iklim tropis dengan cirinya adalah kelembaban dan suhu udara tinggi, dimana rataan suhu harian maksimum $31,32 \pm 1,22^{\circ} \mathrm{C}$ dan minimum $22,44 \pm 1,48^{\circ} \mathrm{C}$ yang setiap tahunnya dapat mengalami fluktuasi sebesar $0,6^{\circ} \mathrm{C}-1{ }^{\circ} \mathrm{C}$ (Syahruddin et al., 2012; Purwantara, 2011).

Perbaikan manajemen pakan perlu dilakukan karena pola konsumsi ayam dipengaruhi oleh kondisi lingkungan sehingga pemberian pakan dilakukan saat nafsu makan tinggi dan lingkungan nyaman. Suhu nyaman untuk ayam di daerah tropis berkisar antara $18-28^{\circ} \mathrm{C}$ dengan kelembaban nyaman yaitu $\leq 70$ dan Heat Stress Index yang masih mampu ditolerir ayam adalah 160 (Ustomo, 2016; Damerow, 2015; Ajakaiye et al., 2011). Pada kondisi nyaman mengakibatkan konsumsi ransum meningkat dan penggunaan ransum efisien, tetapi saat kondisi cekaman panas ayam mengurangi konsumsi ransum serta penggunaan ransum menjadi tidak efisien karena energi banyak digunakan untuk mengurangi beban panas tubuh. Pada suhu diatas thermoneutral zone, menyebakan suhu tubuh ayam naik dan unggas merupakan hewan homoitermik sehingga melakukan usaha untuk menstabilkan suhu tubuh saat cekaman panas dengan cara panting (Gunawan dan Sihombing, 2004).

Berdasarkan suhu yang berfluktuasi tersebut maka perlu diperhitungkan frekuensi pemberian pakan dan awal pemberian pakan. Awal pemberian pakan dilakukan pada pagi hari saat udara masih sejuk dan suhu lingkungan tidak tinggi sehingga energi dari pakan dapat efisien dimanfaatkan untuk pertumbuhan ayam. Pemberian pakan dianjurkan tidak dilakukan pada siang hari karena dapat menambah beban panas tubuh ayam dan meningkatkan stress akibat cekaman panas (Donkoh dan Yirenki, 2000). Selain sifat ayam yang lebih menyukai pakan baru, frekuensi pemberian pakan juga didasarkan pada temperatur tinggi tapi tidak kontinu. Frekuensi pemberian pakan 1 kali, 2 kali dan 3 kali harus disesuaikan dengan fluktuasi suhu pada pagi, siang dan sore hari. Sudah banyak dilakukan penelitian frekuensi pemberian pakan tetapi tidak didasarkan pada fluktuasi suhu. Idayat et al. (2012) melaporkan bahwa frekuensi pemberian pakan 2 kali, 3 kali dan 4 kali tidak memberikan pengaruh nyata terhadap performa ayam pedaging. Didukung Betty et al. (2015) yang melaporkan bahwa pemberian pakan 2 kali (pukul 06:00 dan 18:00 WIB), 3 kali (pukul 06:00, 12:00 dan 18:00 WIB) dan 4 kali (pukul 06:00, 10:00, 14:00 dan 18:00) menunjukkan performa ayam pedaging yang tidak berbeda. 
Berdasarkan berbagai penelitian sebelumya telah diketahui bahwa pemeliharaan pada suhu lingkungan tinggi mampu menurunkan performa ayam dan pemeliharaan pada suhu nyaman mampu menjaga performa ayam. Filho et al. (2010) menyatakan bahwa pemeliharaan pada periode heat stress yaitu suhu $31^{\circ} \mathrm{C}$ dan $36^{\circ} \mathrm{C}$ dapat berpengaruh terhadap penurunan performa ayam meliputi konsumsi pakan, bobot badan dan konversi pakan. Purswell et al. (2012) melaporkan bahwa pemeliharaan pada suhu $21^{\circ} \mathrm{C}$ dengan kelembaban 50-65\% dapat mencegah penurunan performa ayam. Maka penelitian ini bertujuan untuk mengetahui kombinasi frekuensi pemberian pakan dengan awal pemberian pakan yang optimal untuk pemeliharaan ayam buras super.

\section{MATERI DAN METODE}

Pada penelitian ini digunakan 252 ekor anak ayam buras super unsex umur 1 hari dengan bobot badab awal rata-rata $37,88 \pm 1,89 \mathrm{~g}(\mathrm{CV}=5,02 \%)$. Pakan yang digunakan adalah pakan komersial dari PT. Chaeron Pokpand Tbk. Rancangan percobaan yang digunakan adalah Split Plot Design dengan main plot yaitu 3 taraf frekuensi pemberian pakan dan sub plot yaitu 3 taraf awal pemberian pakan dalam 4 ulangan sehingga terdapat 36 unit percobaan, tiap unit percobaan terdiri 7 ekor ayam.
Tabel 1. Kandungan Nutrien Ransum

\begin{tabular}{lcc}
\hline Nutrien & Starter & Finisher \\
\hline KA (\%) & 12,22 & 11,97 \\
PK (\%) & 21,02 & 20,44 \\
LK (\%) & 6,71 & 4,03 \\
SK (\%) & 3,27 & 4,56 \\
Ca (\%) & 1,00 & 0,82 \\
P (\%) & 0,44 & 0,33 \\
EM (Kkal) & $2759,89 *$ & $2601,42 *$ \\
*) EM=40,81 (0,87 (PK +(2,25 x LK)+ BETN) + 2,5) \\
(Carpenter dan Clegg, 1956 dalam Anggorodi, 1985)
\end{tabular}

Perlakuan yang digunakan :

F1A1 : Pemberian pakan 1 kali pada 04:00 WIB,

F1A2 : Pemberian pakan 1 kali pada pukul 06:00 WIB,

F1A3 : Pemberian pakan 1 kali pada pukul 08:00 WIB,

F2A1 :Pemberian pakan 2 kali pada pukul 04:00 dan 17:00 WIB,

F2A2 : Pemberian pakan 2 kali pada pukul 06.00 dan 17:00 WIB,

F2A3 : Pemberian pakan 2 kali pada pukul 08:00 dan 17:00 WIB,

F3A1 : Pemberian pakan 3 kali pada pukul 04:00, 14.00 dan 17:00 WIB,

F3A1 : Pemberian pakan 3 kali pada pukul 06:00, 14.00 dan 17:00 WIB,

F3A1 : Pemberian pakan 3 kali pada pukul 08:00, 14:00 dan 17:00 WIB.

Parameter yang diukur :

Konsumsi ransum (g/ekor) $=$ jumlah konsumsi ransum yang diberikan $(\mathrm{g})$ - sisa ransum $(\mathrm{g})$,

Pertambahan bobot badan (g/ekor) = bobot badan akhir $(\mathrm{g})$ - bobot badan awal (g),

Konversi ransum $=\frac{\text { Jumlah konsumsi ransum }(\mathrm{g})}{\text { Pertambahan bobot badan }(\mathrm{g})}$ 
Income Over Feed Cost $(\mathrm{Rp} / \mathrm{kg})=$ total penjualan $(\mathrm{Rp})$ - biaya ransum (Rp).

Keterangan : Total penjualan = bobot hidup/kg x harga jual/kg

Data yang terkumpul dianalisis dengan analisis ragam Split Plot Design dan uji F pada taraf 5\%. Pada penelitian ini diamati pula kondisi lingkungan yang meliputi suhu, kelembaban dan Indeks Cekaman Panas (Heat Stress Index atau HSI).

Pengukuran HSI dilakukan berdasarkan pendapat Palupi (2015) yang menyatakan Heat Stress Index $={ }^{\circ} \mathrm{F}+\%$ $\mathrm{RH}$ dan suhu ${ }^{\circ} \mathrm{F}=\left(9 / 5 \mathrm{x}^{\circ} \mathrm{C}\right)+32^{\circ} \mathrm{C}$. Rahul dan Pramod (2016) melaporkan nilai HSI maksimum yang dapat diterima oleh ayam adalah 160. Perhitungan menggunakan Fahrenheit dikarenakan skala Fahrenheit lebih akurat dibandingkan dengan skala Celcius dimana rentang satuan skalanya cukup banyak $(212-32)$.

\section{HASIL DAN PEMBAHASAN}

\section{Keadaan Umum}

Hasil penelitian menandakan bahwa sepanjang hari, di dalam maupun di luar kandang memiliki kondisi yang nyaman untuk ayam. Meskipun terdapat periode heat stress pada pukul 12:00 tetapi periode thermoneutral zone berlangsung lebih lama yaitu pagi dan sore. Heat stress yang dialami ayam tergantung dengan lamanya ayam terpapar pada suhu tinggi dan tingkat kelembaban. Gotardo et al. (2015) menyatakan bahwa heat stress dapat terjadi antara pukul 12:00 dan 1:00 siang saat temperatur diatas thermoneutral zone
(TNZ).

Tabel 2. menunjukkan bahwa rataan suhu, kelembaban dan HSI di pagi, siang maupun sore hari termasuk dalam zona nyaman ayam. Tingkat stress tidak hanya berdasarkan suhu, tetapi juga kelembaban maka perlu Heat Stress Index. HSI merupakan indikator stress akibat dari penjumlahan suhu dan kelembaban. Saat suhu lingkungan meningkat pada siang hari dan sore hari, namun kelembaban rendah maka menghasilkan HSI dibawah 160, sehingga masih mampu diterima oleh ayam. Menurut Damerow (2015) suhu nyaman ayam didaerah tropis adalah 18 $28^{\circ} \mathrm{C}$. Tamzil (2014) melaporkan bahwa kelembaban relatif untuk comfort zone ayam adalah 50 - 70\%. Palupi (2015) menyatakan bahwa cekaman panas dialami oleh ayam saat HSI melebihi 160 dan ayam mulai panting.

Kondisi nyaman yang lebih panjang berpengaruh terhadap efisiensi penggunaan ransum dimana energi dari ransum mampu dimanfaatkan dengan optimal untuk produktivitas. Energi dari ransum tidak banyak digunakan untuk heat loss dalam menstabilkan suhu tubuh. Gunawan dan Sihombing (2004) menyatakan bahwa pakan menjadi efisien saat diberikan pada waktu comfort zone ayam karena suhu lingkungan yang tinggi berdampak pada penurunan konsumsi dan menghambat produksi. Mashaly et al. (2014) melaporkan bahwa pemberian pakan pada suhu tinggi berdampak pada penurunan kecernaan ayam dalam mencerna protein untuk pertumbuhan. 
Tabel 2.Rataan suhu, kelembaban (RH) dan heat stress index (HSI)

\begin{tabular}{|c|c|c|c|c|c|c|c|c|}
\hline \multirow{3}{*}{ Waktu } & \multicolumn{4}{|c|}{ Di dalam kandang } & \multicolumn{4}{|c|}{ Di luar kandang } \\
\hline & \multicolumn{2}{|c|}{ Suhu } & \multirow{2}{*}{$\mathrm{RH}(\%)$} & \multirow{2}{*}{ HSI* } & \multicolumn{2}{|c|}{ Suhu } & \multirow{2}{*}{$\mathrm{RH}(\%)$} & \multirow{2}{*}{$\mathrm{HSI}^{*}$} \\
\hline & ${ }^{\circ} \mathrm{C}$ & ${ }^{\circ} \mathrm{F}$ & & & ${ }^{\circ} \mathrm{C}$ & ${ }^{\circ} \mathrm{F}$ & & \\
\hline $4: 00$ & 23,5 & 74,4 & 54,7 & 129,1 & 24,5 & 76,1 & 55,4 & 131,5 \\
\hline $6: 00$ & 24,0 & 75,1 & 59,1 & 134,3 & 24,9 & 76,8 & 60,3 & 137,1 \\
\hline 8:00 & 27,1 & 80,8 & 68,0 & 148,8 & 28,1 & 82,6 & 68,2 & 150,7 \\
\hline $10: 00$ & 30,6 & 87,1 & 69,3 & 156,4 & 31,9 & 89,5 & 69,6 & 159,1 \\
\hline $\begin{array}{c}\text { Rataan } \\
\text { Average }\end{array}$ & 26,3 & 79,4 & 62,8 & 142,2 & 27,4 & 81,2 & 63,4 & 144,6 \\
\hline $12: 00$ & 33,1 & 91,5 & 69,4 & 161,0 & 34,0 & 93,2 & 70,0 & 163,2 \\
\hline $14: 00$ & 31,5 & 88,7 & 65,9 & 154,6 & 32,2 & 89,9 & 68,0 & 157,8 \\
\hline $\begin{array}{l}\text { Rataan } \\
\text { Average }\end{array}$ & 32,3 & 90,1 & 67,6 & 157,8 & 33,1 & 91,6 & 69,0 & 160,5 \\
\hline $17: 00$ & 27,9 & 82,3 & 70,8 & 153,0 & 28,5 & 83,3 & 71,7 & 155,0 \\
\hline $18: 00$ & 28,1 & 82,6 & 69,1 & 151,7 & 28,4 & 83,1 & 71,4 & 154,5 \\
\hline $\begin{array}{l}\text { Rataan } \\
\text { Average }\end{array}$ & 28,0 & 82,4 & 70,0 & 152,4 & 28,4 & 83,2 & 71,6 & 154,8 \\
\hline
\end{tabular}

\section{Konsumsi Ransum}

Hasil penelitian (Tabel 3) menunjukkan bahwa rataan konsumsi ransum untuk masing-masing perlakuan berkisar 3.553,50 - 3.913,17 g/ekor. Hal itu menunjukkan bahwa komsumsi ransum ayam buras super lebih tinggi dibandingkan penelitian Iskandar (2013) yang melaporkan bahwa rataan konsumsi ransum ayam buras super dengan pemeliharaan intensif 12 minggu sebesar $3.348 \mathrm{~g} / \mathrm{ekor}$.

Tabel 3. Rataan konsumsi ransum setiap perlakuan (g/ekor/12 minggu)

\begin{tabular}{ccccc}
\hline Perlakuan & \multirow{2}{*}{ A1 } & A2 & A3 & Rataan \\
\hline & $-0-8$ - & & \\
\hline F1 & $3.824,50$ & $3.913,17$ & $3.855,88$ & $3.864,52$ \\
F2 & $3.619,35$ & $3.858,70$ & $3.736,49$ & $3.738,18$ \\
F3 & $3.562,53$ & $3.553,50$ & $3.780,25$ & $3.632,09$ \\
\hline Rata-rata & $3.668,79$ & $3.775,12$ & $3.790,87$ & \\
\hline
\end{tabular}

Jumlah konsumsi ransum yang lebih tinggi dilatarbelakangi oleh faktor fisiologis. Konsumsi ransum yang besar terjadi akibat ayam dalam keadaan nyaman, dimana tidak mengalami heat stress yang berkepanjangan. Tabel 2. menunjukkan bahwa keadaan umum kandang termasuk thermoneutral zone ayam sehingga berdampak pada besarnya konsumsi ransum. Syafwan et al. (2011) melaporkan bahwa suhu lingkungan yang tinggi berdampak negatif pada penurunan konsumsi ransum sehingga salah satu solusi untuk mencegah heat stress yaitu diperlukan pendekatan thermal conditioning atau pengaturan pemberian 
ransum padasuhu thermoneutral zone (TNZ) ayam.

Hasil analisis ragam menunjukkan bahwa tidak ada pengaruh interaksi frekuensi pemberian pakan dengan awal pemberian pakan $(\mathrm{p}>0,05)$ terhadap konsumsi ransum, demikian pula masingmasing perlakuan tidak berpengaruh nyata ( $>0,05)$ terhadap konsumsiransum. Hal tersebut dikarenakan konsumsi yang sama dengan kandungan nutrien yang sama serta kondisi lingkungan dibawah HSI mengakibatkan efisiensi penggunaan ransum tidak berbeda. Konsumsi ransum tergantung pada fisiologis lingkungan (Tabel 2) dimana meskipun ada suhu stress tetapi suhu nyaman lebih lama dan diimbangi kelembaban yang rendah sehingga HSI juga rendah dan mengakibatkan konsumsi ransum tidak berbeda. Butcher dan Miles (2015) menyatakan bahwa energi dalam pakan banyak terbuang saat temperatur tinggi akibat usaha ayam untuk menghilangkan panas sehingga diperlukan formulasi ransum dengan kepadatan nutrien yang tinggi. Rahul dan Pramod (2016) menyatakan bahwa saat suhu di dalam kandang berada di bawah $27,7{ }^{\circ} \mathrm{C}$ dengan kelembaban relatif yang rendah maka penjumlahan suhu dan kelembaban masih berkisar 160 dan mengakibatkan suasana nyaman di dalam kandang sehingga konsumsi pakan ayam tidak mengalami penurunan.

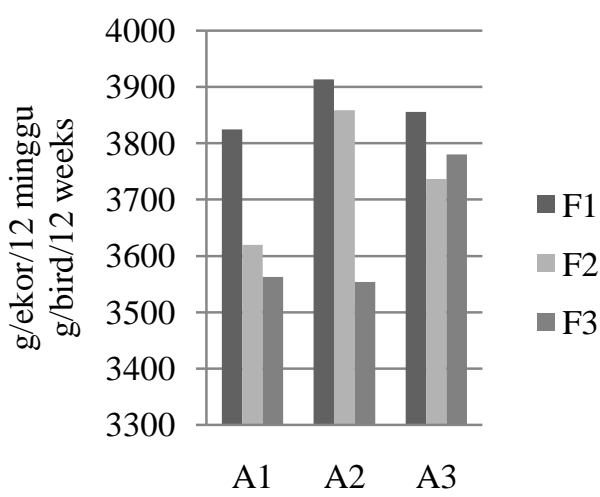

Gambar 1. Grafik Konsumsi Ransum

Hasil penelitian pada Gambar 1. menunjukkan bahwa jika dilihat secara numerikal, kombinasi perlakuan yang menunjukkan hasil terbaik adalah F1A2. Hal itu dikarenakan kondisi nyaman yang panjang berpengaruh pada efisiensi energi ransum tidak terbuang untuk pengeluaran panas tubuh saat heat stress. Pemberian pakan pukul 06:00 dengan frekuensi 1 kali mengakibatkan pakan selalu tersedia saat ayam merasa lapar sehingga tidak terjadi pembongkaran energi. Isroli (1996) menyatakan bahwa lapar, nafsu makan dan rasa kenyang berhubungan dengan waktu penyajian ransum dan fungsi sistem saraf pusat (hypotalamus) serta mekanisme inhibitory (pembatasan di pusat kenyang) terhadap respon makan. Lin et al. (2006) melaporkan bahwa jumlah ransum yang dikonsumsi ayam dipengaruhi oleh kemampuan ayam dalam memperlihatkan respon terhadap heat stress.

\section{Pertambahan Bobot Badan}

Hasil penelitian (Tabel 4) menunjukkan bahwa rataan pertambahan bobot badan ayam buras super untuk masing-masing perlakuan berkisar 1078,66 
- 1.229,29 g/ekor. Hasil tersebut tidak berbeda dengan penelitian Sopian et al. (2015) yang melaporkan bahwa rataan pertambahan bobot badan ayam buras super yang dipelihara secara intensif selama 12 minggu adalah 1.113 g/ekor. Pertambahan bobot badan dipengaruhi oleh jumlah konsumsi ransum. Konsumsi ransum ayam optimal dan penggunaan energi menjadi efisien untuk meningkatkan bobot badan saat tidak ada cekaman panas sehingga tidak banyak energi yang digunakan untuk heat loss. HSI yang masih dibawah 160 mengakibatkan pertambahan bobot badan tidak terhambat akibat ayam mampu mencerna nutrien ransum dengan baik. Tabiri et al. (2002) melaporkan bahwa kondisi stress ayam dapat dialami saat temperatur mencapai $36^{\circ} \mathrm{C}$ dimana hal itu berdampak pada penurunan bobot badan yang signifikan akibat lemahnya kemampuan mencerna zat-zat nutrien pakan.

Tabel 4. Rataan pertambahan bobot badan tiap perlakuan (g/ekor/12 minggu)

\begin{tabular}{ccccc}
\hline Perlakuan & A1 & A2 & A3 & Rataan \\
\hline & $-1.131,16$ & $1.229,29$ & $1.141,44$ & $1.167,30$ \\
F1 & $1.078,66$ & $1.198,32$ & $1.153,66$ & $1.143,54$ \\
F2 & $1.153,86$ & $1.111,84$ & $1.176,72$ & $1.147,47$ \\
\hline Fata-rata & $1.121,23$ & $1.179,81$ & $1.157,27$ & \\
\hline
\end{tabular}

Hasil analisis ragam menunjukkan bahwa tidak ada pengaruh interaksi frekuensi pemberian pakan dengan awal pemberian pakan $(\mathrm{p}>0,05)$ terhadap pertambahan bobot badan, demikian pula masing-masing perlakuan tidak berpengaruh nyata $(p>0,05)$ terhadap pertambahan bobot badan. Hal tersebut dapat dipengaruhi oleh HSI dibawah 160 sehingga saat ayam pada comfort zone energi dari ransum dapat terdeposisi dengan baik untuk pertumbuhan dan pertambahan bobot badan tidak berbeda. Paparan heat stress yang berlangsung singkat (Tabel 2.) mengakibatkan tidak terganggunya metabolisme di dalam tubuh untuk pertambahan bobot badan. Olanrewaju et al. (2010) melaporkan bahwa cekaman panas menghambat suplai nutrien ke jaringan tubuh sehingga berpengaruh terhadap penurunan efisiensi dari absorbsi nutrien untuk produksi dalam meningkatkan bobot tubuh. Lara dan Rostagno (2013) menyampaikan bahwa ayam yang mengalami heat stressakibat suhu lingkungan tinggi dalam jangka waktu lama mampu menjadi penyebab penurunan bobot badan hingga 30\% akibat penurunan konsumsi ransum hingga $16 \%$.

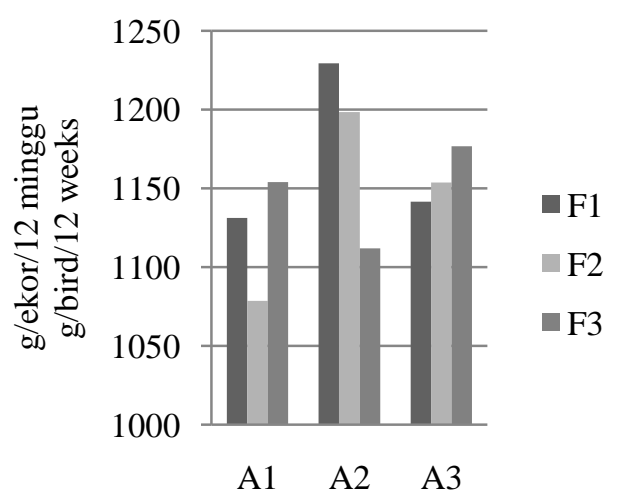

Gambar 2. Grafik PBB 
Hasil penelitian pada Gambar 2. menunjukkan bahwa jika dilihat secara numerikal, kombinasi perlakuan terbaik adalah F1A2. Hal itu dikarenakan ayam mampu beradaptasi dengan keadaan lingkungan dimana berdasarkan Tabel 2 . terlihat bahwa meskipun suhu tinggi pada siang hari tetapi kelembaban tetap berkisar nyaman sehingga sepanjang hari kondisi lingkungan dapat ditolerir ayam. Faktor lain yang berpengaruh adalah ayam dapat mengatur konsumsi pakannya dengan baik pada saat memerlukan energi karena pakan yang selalu tersedia dan kondisi lingkungan yang nyaman. Sinurat dan Balnave (1986) menyatakan bahwa ayam mampu mengatur jumlah pasokan energi untuk memenuhi kebutuhan hidup pokok dan produksi sehingga ayam berhenti makan saat absorbsi nutrien mencukupi kebutuhan. Furlan et al. (2004) melaporkan bahwa kenaikan temperatur yang diikuti oleh kenaikan suhu tubuh mengakibatkan pengeluaran energi untuk mengurangi beban panas tubuh sehingga mengganggu kecernaan, penyerapan dan metabolisme nutrien untuk pertambahan bobot tubuh ayam.

\section{Konversi Ransum}

Hasil penelitian (Tabel 5) menunjukkan bahwa konversi ransum ayam buras super untuk masing-masing perlakuan berkisar $3,10-3,40$. Hal ini lebih baik dari hasil penelitian Iskandar (2013) yang melaporkan bahwa rataan konversi ransum ayam buras super yang dipelihara secara intensif selama 12 minggu adalah 4,2. Hal tersebut mengindikasikan bahwa kemampuan ayam dalam mencerna zat-zat nutrien ransum untuk dikonversi menjadi daging sangat baik. Temperatur nyaman yang berdurasi lebih lama dari cekaman panas mengakibatkan ayam memiliki waktu yang cukup dalam memenuhi kebutuhan energi untuk pertumbuhan bobot tubuh. Furlan et al. (2004) menyatakan bahwa ayam yang terkena heat stress dapat mengalami penurunan bobot badan lebih besar dibandingkan dengan penurunan konsumsi pakan karena sebagian dari energi metabolisme digunakan untuk menghilangkan panas sehingga meningkatkan nilai konversi ransum.

Tabel 5. Rataan konversi ransum tiap perlakuan (12 minggu)

\begin{tabular}{ccccc}
\hline Perlakuan & A1 & A2 & A3 & Rataan \\
\hline F1 & 3,39 & 3,18 & 3,40 & 3,32 \\
F2 & 3,37 & 3,23 & 3,25 & 3,28 \\
F3 & 3,10 & 3,20 & 3,22 & 3,17 \\
\hline Rata-rata & 3,28 & 3,20 & 3,29 & \\
\hline
\end{tabular}

Hasil analisis ragam menunjukkan bahwa tidak ada pengaruh interaksi frekuensi pemberian pakan dengan awal pemberian pakan $(p>0,05)$ terhadap konversi ransum, demikian pula masingmasing perlakuan tidak berpengaruh nyata ( $p>0,05)$ terhadap konversi ransum. Hal itu dikarenakan suhu dan kelembaban pada 
kisaran nyaman sehingga nilai HSI menjadi rendah yaitu dibawah 160. Maka saat kondisi nyaman, absorbsi nutrien ransum berjalan dengan baik untuk produksi sehingga konversi ransum tidak berbeda. Sugito dan Delima (2009) menyatakan bahwa temperatur dan kelembaban yang nyaman menyebabkan tercukupinya asupan energi dari ransum sehingga dapat meningkatkan efisiensi penggunaan ransum (nilai FCR yang lebih rendah). Olanrewaju et al. (2010) melaporkan bahwa ayam merasa paling nyaman, lebih produktiv, dan tingkat stress minimum ketika temperatur lingkungan pada TNZayam.

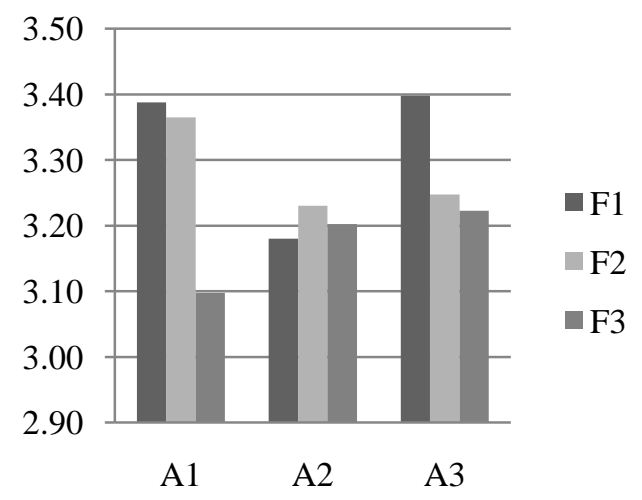

Gambar 3. Konversi Ransum

Hasil penelitian pada Gambar 3. menunjukkan bahwa jika dilihat secara numerikal, kombinasi perlakuan terbaik adalah F3A1. Hal itu dikarenakan frekuensi pemberian pakan 3 kali dengan awal pemberian pakan pukul 04:00 dapat memberi kesempatan ayam mengatur energi ransum untuk hidup pokok dan pertumbuhan dengan baik yang dilatarbelakangi oleh periode nyaman lebih panjang dibanding periode stress. Maka konsumsi energi yang diperoleh dari ransum cukup untuk dikonversi menjadi daging sehingga nilai FCR tidak tinggi. Daghir et al. (2009) menyatakan bahwa temperatur yang tinggi dapat mengurangi efisiensi penggunaan energi ransum untuk tujuan produksi dan nilai FCR mengalami fluktuasi sejalan dengan perubahan temperatur lingkungan. Jahejo et al. (2016) melaporkan saat cekaman panas berlangsung, sebagian besar energi yang seharusnya digunakan dalam proses produksi dialihkan untuk mengatur termoregulasi tubuh sehingga berdampak pada tingginya konversi ransum.

\section{Income Over Feed Cost (IOFC)}

Hasil penelitian pada Tabel 6 . menunjukkan bahwa IOFC yang digunakan sebagai standar pelaksanaan praktis adalah F2A2. Maka untuk mengatahui tingkat keuntungan akibat perlakuan, IOFC dari masing-masing perlakuan dibandingkan dengan sistem pemeliharaan standar yang sering digunakan masyarakat. Perlakuan yang menghasilkan keuntungan ekonomis terbaik adalah pada perlakuan F3A1 yaitu Rp 7.670 dengan persentase 10,56\%.

Hasil tersebut lebih tinggi dari penelitian Iskandar (2012) yang menyatakan bahwa Income Over Feed Cost dari ayam buras super yang dipelihara secara intensif selama 12 minggu sebesar Rp 4.156. Hal tersebut dapat dipengaruhi oleh konsumsi ransum ayam yang sesuai dengan kebutuhan sehingga energi ransum mampu dimanfaatkan dengan baik untuk pertambahan bobot badan. Maka jumlah konsumsi ransum tidak semakin banyak 
dan IOFC semakin besar. Wiradimaja et al. (2015) menyatakan bahwa besarnya Income Over Feed Cost bergantung pada pertambahan bobot badan ayam, karena semakin efisien ayam mengubah nutrien dalam ransum menjadi daging maka IOFC semakin baik. Faktor lain yang melatarbelakangi adalah kondisi nyaman selama pemeliharaan sehingga ayam berhenti makan saat kebutuhan energi sudah terpenuhi. Olanrewaju et al. (2010) menyatakan nilai efisiensi ransum terbaik dapat diperoleh saat suhu lingkungan optimum karena energi tidak banyak terbuang saat heat loss.

Tabel 6. Income over feed cost (IOFC) (Rp/kg/12 minggu)

\begin{tabular}{ccccc}
\hline Perlakuan & $\begin{array}{c}\text { Total pendapatan } \\
(\mathrm{Rp})\end{array}$ & $\begin{array}{c}\text { Total biaya pakan } \\
(\mathrm{Rp})\end{array}$ & $\begin{array}{c}\text { IOFC }(\mathrm{Rp}) \\
(\mathrm{Rp})\end{array}$ & $\begin{array}{c}\text { IOFC }(\%)^{*} \\
(\%)^{*}\end{array}$ \\
\hline F1A1 & 32.760 & 27.536 & 5.224 & $-24,70$ \\
F1A2 & 35.560 & 28.175 & 7.385 & 6,46 \\
F1A3 & 33.040 & 27.779 & 5.261 & $-24,16$ \\
F2A1 & 31.360 & 26.059 & 5.301 & $-23,59$ \\
F2A2 & 34.720 & 27.783 & 6.937 & Standar \\
F2A3 & 33.320 & 26.903 & 6.417 & $-7,50$ \\
F3A1 & 33.320 & 25.650 & 7.670 & $10,56^{* *}$ \\
F3A2 & 32.300 & 25.585 & 6.615 & $-4,65$ \\
F3A3 & 33.880 & 27.218 & 6.662 & $-3,97$ \\
\hline
\end{tabular}

*) Besarnya tingkat IOFC yang dibandingkan dengan standar

**) Keuntungan ekonomis tertinggi

\section{KESIMPULAN}

Kesimpulan dari penelitian ini adalah frekuensi pemberian pakan tidak berinteraksi dengan awal pemberian pakan, demikian pula masing-masing perlakuan tidak berpengaruh nyata terhadap performa ayam buras super. Jika dilihat dari keuntungan ekonomis, kombinasi perlakuan F3A1 (frekuensi pemberian pakan 3 kali dengan awal pemberian pakan pukul 04:00) memberikan hasil Income Over Feed Cost tertinggi.

\section{DAFTAR PUSTAKA}

Ajakaiye, J., B. A. Perez and T. A. temperature on production in layer chicken supplemented with vitamins $\mathrm{C}$ and $\mathrm{E}$. Revista MVZ Cordoba. 16(1): 2283-2291.

Anggorodi, R. 1985. Ilmu Makanan Ternak Unggas. PT. Gramedia Pustaka Utama, Jakarta.

Betty, H., R. Novita dan T. Karyono. 2015. Pengaruh jenis dan waktu pemberian ransum terhadap performans pertumbuhan dan produksi ayam broiler. J. Sains Peternakan Indonesia. 10(2): 107113.

Mollineda. 2011. Effect of high 
Butcher, G. D. and R. Miles. 2015. Heat stress management in broilers. IFAS Extension.Univ. of Florida.

Daghir, N. J., Beirut and Lebanon. 2009. Nutritional strategies to reduce heat stress in broilers and broiler breeders. World's Poult. Sci. J. 44(1): 6-15.

Damerow, G. 2015. The chicken health handbook :acomplete guide to maximizing flock health and dealing with disease. $2^{\text {th }}$ edn. Storey Publishing, North Adams.

Donkoh, A. and K. Yirenki. 2000. Respond of broiler chicken to different feeding time in the hot humid tropics. Ghana J. Agric. Sci. 33: 79- 85 .

Filho, W. M. Q., A. Ribeiro, V. Ferraz-dePaula, M. L. Pinheiro, M. Sakai, L. R. M. Sa, A. J. P. Ferreira and J. Palermo-Neto. 2010. Heat stress impairs performance parameters, induces intestinal injury, and decreases macrophage activity in broiler chickens. Poult. Sci. 89: 1905-1914.

Furlan, R. L., D. E. F. Filho, P. S. Rosa and M. Macari. 2004. Does lowprotein diet improve broiler performance under heat stress conditions.Brazillian J. of Poult. Sci. 6(2): 71-79.
Gotardo, L. R. M., P. B. Vieira, C. F. P. Marchini, M. R. B. de Mattos Nasciment, R. C. Antunes, E. C. Guimaraes, J. P. R. Bueno and D. B. Santos. 2015. Cyclic heat stress in broilers and their effects on quality of chicken breast meat. Acta Sci. Vet. 43: 13-25.

Gunawan dan D. T. H. Sihombing. 2004. Pengaruh suhu lingkungan tinggi terhadap kondisi fisiologis dan produktivitas ayam buras. Wartazoa. 14(1): 31-38.

Idayat, A., U. Atmomarsono dan W. Sarengat. 2012. Pengaruh berbagai frekuensi pemberian pakan pada pembatasan pakan terhadap performans ayam broiler. Anim. Agric. J. 1(1): 379-388.

Iskandar, S. 2012. Optimalisasi protein dan energi ransum untuk meningkatkan produksi daging ayam lokal.Prosiding Pengembangan Inovasi Pertanian.Bogor, Juli 2011. 5(2): 96-107.

Iskandar, S. 2013. Pertumbuhan ayamayam lokal sampai dengan umur 12 minggu pada pemeliharaan intensif.Prosiding Lokakarya Nasional Inovasi Teknologi Pengembangan Ayam Lokal.Bogor, Juli 2012. 9 (1): 132-137. 
Isroli. 1996. Penagturan konsumsi energi pada ternak. Sainteks. 3: 64-73.

Jahejo, A. R., N. Rajput, N. M. Rajput, I. H. Leghari, R. R. Kaleri, R. A. Mangi, M. K. Sheikh and M. Z. Pirzado. 2016. Effects of heat stress on the performance of hubbard broiler chicken. Chells, Anim. and Terapheutics. 2(1): 1-5.

Lara, L. J. and M. H. Rostagno. 2013. Impact of heat stress on poultry production. Anim. J. 3: 356-369.

Lin, H., H. C. Jiao, J. Buyse and E. Decuypere. 2006. Strategies for preventing heat stress in poultry. World's Poult. Sci. J. 62: 71-85.

Mashaly, M. M., G. L. Hendricks, M. A. Kalaman, A. E. Gehad, A. O. Abbas and P. H. Patterson. 2004. Effect of heat stress on production parameters and immune responses of commercial laying hens. Poult. Sci. 83: 889-894.

Muryanto, D., T. Pramono, S. Prasetyo, H. Prawirodigdo, E. Mumpuni, E. Kushartini dan I. Musawati. 2009. Rekomendasi Paket Teknologi Pertanian Provinsi Jawa Tengah, Bidang Penelitian dan Pengembangan Pertanian Balai Pengkajian Teknologi Pertanian Jawa Tengah 2009.

Olanrewaju, H. A., J. L. Purswell, S.D. Collier and S.L. Branton. 2010.
Effect of ambient temperature and light intensity on growth performance and carcass characteristics of heavy broiler chickens at 56 days of age. Int. J. of Poult. Sci. 9(8): 720-725.

Palupi, R. 2015. Manajemen mengatasi heat stess pada ayam broiler yang dipelihara dilahan kering. Prosiding Seminar Nasional Lahan Suboptimal, Palembang, Oktober 2015. Hlm: 1-9.

Purswell, J. L., W. A. Dozier, H. A. Olanrewaju, J. D. Davis, H. Xin and R. S. Gates. 2012. Effect of temperature-humidity index on live performance in broiler chickens grown from 49 to 63 days of age. Ninth International Livestock Environment Symposium.Valencia, Juli 2012. p. 1-9.

Purwantara, S. 2011. Studi temperatur udara terkini di wilayah di Jawa Tengah dan DIY.Informasi. 27(2): 166-179.

Rahul, R. and K. Pramod. 2016. Heat stress management practices in poultry. Int. J. for Scientific Research and Development. 4 (2): 76-79.

Sinurat, A. P. and D. Balnave. 1986. Free choice feeding at high temperature. Brit. Poult. Sci. 29: 55-58. 
Sopian, Y., S. Darwati dan C. Sumantri.2015. Performa F1 antara ayam sentul $\mathrm{x}$ kampung dan ayam pelung $\mathrm{x}$ sentul pada umur 0-12 minggu.J. Ilmu Produksi dan Teknologi Hasil Peternakan. 3 (3): 131-137.

Sugito dan M. Delima. 2009. Dampak cekaman panas terhadap pertambahan bobot badan, rasio heterofil : limfosit dan suhu tubuh ayam broiler. J. Kedokteran Hewan. 3(1): 218-226.

Syafwan, S., R. P. Kwakkel and M. W. A. Verstegen. 2011. Heat stress and feeding strategies in meat type chickens. World's Poult. Sci J. 67: 653-673.

Syahruddin, E., H. Abbas, E. Purwati dan Y. Heryandi. 2012. Aplikasi mengkudu sebagai sumber antioksidan untuk mengatasi stres ayam broiler di daerah tropis. J.
Peternakan Indonesia. 14 (3): 411-424.

Tabiri, H. Y., K. Sato, K. Takahashi, M. Toyomizu and Y. Akiba. 2002. Effects of heat stress and dietary tryptophan on performance and plasma amino acid concentrations of broiler chickens. J of Anim. Sci. 15(37) : 247-253.

Tamzil, M. H. 2014. Stres panas pada unggas: metabolisme, akibat dan upaya penanggulangannya. Wartazoa. 24 (2): 57-66.

Ustomo, E. 2016. 99\% Gagal beternak ayam broiler. Cet 1. Penebar Swadaya, Jakarta.

Wiradimadja, R., W. Tanwiriah dan D. Rusmana. 2015. Efek pemberian belimbing wuluh dan ransum terhadap performans, karkas dan income over feed cost ayam kampung. Ziraa'ah. 40 (2): 86-91. 